\title{
The ElAsticity OF DERIVED DEMAND, FACTOR SUBSTITUTION AND PRODUCT DEMAND: CORRECTIONS TO HICKS' FORMULA AND MARSHALL'S FOUR RULES
}

\author{
ROBERT S. CHIRINKO \\ DEBDULAL MALLICK
}

CESIFO WORKING PAPER NO. 1742

CATEGORY 1: PUBLIC FinANCE

JUNE 2006

An electronic version of the paper may be downloaded

- from the SSRN website:

wWw.SSRN.com

- from the RePEc website:

Www.RePEc.org

- from the CESifo website:

www.CESifo-group.de 


\title{
THE ELASTICITY OF DERIVED DEMAND, FACTOR SUBSTITUTION AND PRODUCT DEMAND: CORRECTIONS TO HICKS’ FORMULA AND MARSHALL'S FOUR RULES
}

\begin{abstract}
Nearly 75 years ago, John Hicks introduced and formalized the concept of the elasticity of substitution between capital and labour and its relation to derived demand. The resulting formula has proven very useful in understanding the derived demand for productive factors, the distribution of factor incomes, and Marshall's Four Rules. This short paper notes that a slip occurred in the original derivation, presents a modified formula, and shows that Marshall's First Rule is no longer generally valid.
\end{abstract}

JEL Code: D21, D33, J23, A2.

Keywords: derived demand, substitution elasticity, John Hicks.

Robert S. Chirinko Department of Economics Emory University Atlanta, Georgia 30322-2240 USA robert.chirinko@emory.edu
Debdulal Mallick

Department of Economics

Emory University

Atlanta, Georgia 30322-2240

USA

May 2006

The authors thank Len Carlson, Hugo Mialon, and John van Reenan for helpful comments. All errors, omissions, and conclusions remain the sole responsibility of the authors. 


\section{The Elasticity Of Derived Demand, Factor Substitution, And Product Demand: \\ Corrections To Hicks' Formula And Marshall's Four Rules}

Nearly 75 years ago, John Hicks introduced and formalized the concept of the elasticity of substitution between capital and labour. Hicks' substantial achievement in The Theory of Wages (1932/1963) was to develop a serviceable formal framework with which to analyze the concept and its implications for demand theory. These efforts yielded an important formula linking the derived demand for a factor of production to the extent to which it substituted with other factors, its importance in production, the availability of competing factors, and the ultimate demand for the good produced. This formula proved valuable in evaluating Marshall's Four Rules of derived demand and continues in use today. Leading U.S. labour economics texts discuss Hicks' formula and Marshall's Four Rules. ${ }^{1}$ Molina (2005) relies on Hicks formula in analyzing capital theory debates, and Chirinko and Mallick (2006) use it for inferring macro production function parameters from estimates based on micro data. Hamermesh (1993, Chapter Two, especially equation $\left(2.7 a^{\prime}\right)$ ) evaluates extant empirical labour demand studies with the Hicks formula, which he refers to as "the fundamental law of factor demand" (p. 24).

However, a slip occurred in deriving the original formula. Hicks and later Allen (1938/1964) assumed that factor shares are constant. While this assumption is appropriate when the substitution elasticity is unity, we now know with the benefit of the celebrated article by Arrow, Chenary, Minhaus, and Solow $(1961 / 1985)$ that factor shares vary with relative factor prices when the substitution

\footnotetext{
${ }^{1}$ See Borjas (2005, pp. 130-132), Ehrenberg and Smith (2006, pp. 96-99), and Kaufman and Hotchkiss (2003, pp. 234-238).
} 
elasticity differs from unity. This note presents a modified formula that recognizes variation in factor shares. Section 1 introduces the formula and notation used originally by Hicks. Section 2 offers a new derivation based on the CES production function. Given its wide currency, the constant elasticity of substitution (CES) production function is used to establish the required modification to the Hicks formula for a range of values of the substitution elasticity. When factor shares are constant, the original and modified formulas are identical. In light of the modified formula, Section 3 re-evaluates Marshall's Four Rules, and we show that the First Rule no longer holds in general when the substitution elasticity differs from unity.

\section{Hicks' Formula}

The original formula was presented by Hicks (1932/1963) in Appendix (iii) and is based on a neoclassical production function, $x=f[a, b]$, relating output $(x)$ to two inputs $(a, b)$. The formula is stated in terms of four elasticities and the factor share for $\mathrm{a}:^{2}$

The elasticity of substitution between factors a and $b$,

$$
\begin{aligned}
\sigma & \equiv\left(\mathrm{f}_{\mathrm{a}} \mathrm{f}_{\mathrm{b}}\right) /\left(\mathrm{f}_{\mathrm{ab}} \mathrm{x}\right), \\
& =-((\mathrm{da} / \mathrm{a})-(\mathrm{db} / \mathrm{b})) /\left(\left(\mathrm{dp}_{\mathrm{a}} / \mathrm{p}_{\mathrm{a}}\right)-\left(\mathrm{dp}_{\mathrm{b}} / \mathrm{p}_{\mathrm{b}}\right)\right), \\
& =-(\mathrm{d} \log (\mathrm{a} / \mathrm{b})) /\left(\mathrm{d} \log \left(\mathrm{p}_{\mathrm{a}} / \mathrm{p}_{\mathrm{b}}\right)\right),
\end{aligned}
$$

\footnotetext{
${ }^{2}$ The only changes in notation from Hicks are to introduce explicit notation for the production function (f[.]), replace the partial derivatives $\mathrm{x}_{\mathrm{a}}, \mathrm{x}_{\mathrm{b}}$, and $\mathrm{x}_{\mathrm{ab}}$ by $\mathrm{f}_{\mathrm{a}}, \mathrm{f}_{\mathrm{b}}$, and $\mathrm{f}_{\mathrm{ab}}$, respectively, and substitute factor prices for their marginal products.
} 
The price elasticity of demand for factor a,

$$
\lambda \equiv-(\partial \mathrm{a} / \mathrm{a}) /\left(\partial \mathrm{p}_{\mathrm{a}} / \mathrm{p}_{\mathrm{a}}\right),
$$

The price elasticity of demand for the product $\mathrm{x}$,

$$
\eta \equiv-(\partial x / x) /\left(\partial p_{x} / p_{x}\right)
$$

The price elasticity of supply of the substitute factor $b$,

$$
\mathrm{e} \equiv(\partial \mathrm{b} / \mathrm{b}) /\left(\partial \mathrm{p}_{\mathrm{b}} / \mathrm{p}_{\mathrm{b}}\right)
$$

The factor shares for $a$ and $b$, respectively,

$$
\begin{gathered}
\kappa \quad \equiv\left(p_{a} a\right) /\left(p_{x} x\right), \\
1-\kappa \equiv\left(p_{b} b\right) /\left(p_{x} x\right) .
\end{gathered}
$$

The elasticity of substitution between factors $a$ and $b$ can be represented in three equivalent ways. Equation (1a) is the original formulation by Hicks. Robinson $(1933 / 1959$, p. 256) independently introduced the substitution elasticity as specified in equations (1b) and (1c). Hicks (1963, Section VII, "Notes on the Elasticity of Substitution", sub-section 1) showed that the two formulations are equivalent, though Robinson's definition has proven the more convenient and popular. Note that equations (5a) and (5b) state that factor shares are constant.

Computing a series of total derivatives, exploiting the linear homogeneity of the production function, and using the above relations, Hicks (1963, pp. 242-244) derives the following formula for the elasticity of the derived demand for factor $a{ }^{3}$

3 See Allen (1938/1964, Section 14.8) for an alternative derivation. 


$$
\lambda=\frac{\sigma(\eta+\mathrm{e})+\mathrm{e}(\eta-\sigma) \kappa}{\eta+\mathrm{e}-(\eta-\sigma) \kappa} .
$$

To better focus attention on the slip that has occurred in deriving equation (6), we examine the simpler formula based on an infinitely elastic supply of the substitute factor of production. Letting e $\rightarrow \infty$, equation (6) can be rewritten as follows,

$$
\begin{aligned}
& \lambda=\sigma-\kappa \sigma+\kappa \eta, \\
& \lambda=\sigma+(\eta-\sigma) \kappa,
\end{aligned}
$$

Equation (7a) captures in a succinct manner the substitution and scale effects associated with a decline of the factor price of a on its derived demand. As represented by the first term, there is a direct substitution effect holding output price and output constant. The second term represents an additional indirect substitution effect driven by the lower marginal cost of production. Under competitive conditions, the decline in marginal cost translates into a decline in the output price. The extent of this decline is determined by the relative importance of factor a in production represented by its factor share $(\kappa)$. The decline in output price raises the relative price of and lowers the demand for factor a. The third effect occurs because the lower factor price allows the firm to slide down the product demand curve and increase output. This scale effect is represented by the product of $\kappa$ and the demand elasticity $(\eta)$ in the third term of equation (7a).

\section{A New Derivation and A Modification}

To highlight the roles of the substitution elasticity and factor shares, we develop our modified formula from the following CES production function, 


$$
\mathrm{x}=\left\{\phi \mathrm{a}^{[(\sigma-1) / \sigma]}+(1-\phi) \mathrm{b}^{[(\sigma-1) / \sigma]}\right\}^{[\sigma /(\sigma-1)]},
$$

where $\phi$ is the distribution parameter. Assuming that the firm is maximizing profits subject to this CES production function and a vector of prices, the firstorder condition for factor a is as follows,

$$
\mathrm{a}=\phi^{\sigma}\left(\mathrm{p}_{\mathrm{a}} / \mathrm{p}_{\mathrm{x}}\right)^{-\sigma} \mathrm{x}
$$

Since output $(x)$ and output price $\left(p_{x}\right)$ will vary with the factor price $\left(p_{a}\right)$, they must be restated in terms of factor prices and parameters describing the technology and the output market. If the output market is competitive and the production function is linear homogeneous, output price equals marginal cost that, in turn, equals average cost. The latter is specified by starting with the basic cost function as the sum of the purchase costs of each factor and using equation (9) and the kindred relation for factor $b$ to obtain the following expression for average cost qua output price,

$$
\mathrm{p}_{\mathrm{x}}=\left(\phi^{\sigma} \mathrm{p}_{\mathrm{a}}{ }^{(1-\sigma)}+(1-\phi)^{\sigma} \mathrm{p}_{\mathrm{b}}{ }^{(1-\sigma)}\right)^{(1 /(1-\sigma))} .
$$

We assume that industry product demand is described by the following constant elasticity function,

$$
\mathrm{x}=\mathrm{p}_{\mathrm{x}}^{-\eta} \mathrm{W},
$$

where $\mathrm{W}$ represents a set of exogenous variables that affect the demand. 
Substituting equation (11) into (9) and equation (10) into the resulting expression, we obtain the following equation for the derived demand for factor a,

$$
\mathrm{a}=\phi^{\sigma} \mathrm{p}_{\mathrm{a}}{ }^{-\sigma}\left(\phi^{\sigma} \mathrm{p}_{\mathrm{a}}^{(1-\sigma)}+(1-\phi)^{\sigma} \mathrm{p}_{\mathrm{b}}^{(1-\sigma)}\right)^{((\sigma-\eta) /(1-\sigma))} \mathrm{W}
$$

Differentiation of equation (12) with respect to the factor price of a and some transformations yield the following modified formula for the price elasticity of demand for factor $\mathrm{a}, \lambda^{*}$,

$$
\begin{aligned}
\lambda^{*}=\sigma & +(\eta-\sigma) \mu\left[\phi,\left(\mathrm{p}_{\mathrm{a}} / \mathrm{p}_{\mathrm{x}}\right), \sigma\right], \\
& \mu\left[\phi,\left(\mathrm{p}_{\mathrm{a}} / \mathrm{p}_{\mathrm{x}}\right), \sigma\right] \equiv \phi^{\sigma}\left(\mathrm{p}_{\mathrm{a}} / \mathrm{p}_{\mathrm{x}}\right)^{(1-\sigma)}, \\
& \mu\left[\phi,\left(\mathrm{p}_{\mathrm{a}} / \mathrm{p}_{\mathrm{x}}\right), \sigma=1\right]=\phi . \\
& \partial \mu / \partial \sigma=\left(\operatorname{Ln}[\phi]-\operatorname{Ln}\left[\mathrm{p}_{\mathrm{a}} / \mathrm{p}_{\mathrm{x}}\right]\right) \mu>=<0 .
\end{aligned}
$$

The difference between the original (cf. equation (7b)) and modified formulas is represented by $\mu\left[\phi,\left(\mathrm{p}_{\mathrm{a}} / \mathrm{p}_{\mathrm{x}}\right), \sigma\right]$ defined in equation $(13 \mathrm{~b})$, which depends on the CES distribution and substitution parameters and the factor price ratio. When $\sigma$ takes on the restrictive Cobb-Douglas value of unity, $\mu\left[\phi,\left(\mathrm{p}_{\mathrm{a}} / \mathrm{p}_{\mathrm{x}}\right), \sigma\right]$ reduces to $\phi$ (equation (13(c)), and there is no discrepancy between Hicks' original formula and $\lambda^{*}$. For general values of the substitution

\footnotetext{
${ }^{4}$ Consistent with the assumption that the supply of factor $\mathrm{b}$ is infinitely elastic, we assume that variations in $\mathrm{p}_{\mathrm{a}}$ do not affect $\mathrm{p}_{\mathrm{b}}$. If this assumption is relaxed, then the derivation becomes more complicated; we need to also analyze the derived demand for factor $b$ (similar to equation (12)), differentiate this equation with respect to $\mathrm{p}_{\mathrm{a}}$, and use the resulting relations to eliminate the cross-price elasticity. Details are provided in the Appendix. The end result is that equation (13a) is replaced by equation (6) with the $\kappa$ 's removed in favour of the $\mu[$.$] in equation (13b).$
} 
parameter, however, the elasticity formula must account for the variability in factor shares due to the relative price term and the substitution elasticity. ${ }^{5}$

This analysis of the CES production function suggests a "shortcut" method for modifying the elasticity formula. The slip in the derivations by Hicks and Allen occurred in treating the factor share of a as a constant. This assumption was imposed toward the end of their derivations and did not affect the evaluation of their differentials. Consequently, it is valid to merely use the CES production function to derive the appropriate expression for the factor share of a and to insert it into the original formula. We begin with the factor share of a (equation (5a)),

$$
\begin{aligned}
\kappa & \equiv\left(p_{a} a\right) /\left(p_{x} x\right) \\
& =\left(p_{a} / p_{x}\right)(a / x),
\end{aligned}
$$

and use the first-order condition for factor a (equation (9)) to eliminate (a / $\mathrm{x}$ ),

$$
\begin{aligned}
\kappa & =\phi^{\sigma}\left(\mathrm{p}_{\mathrm{a}} / \mathrm{p}_{\mathrm{x}}\right)^{(1-\sigma)} \\
& =\mu\left[\phi,\left(\mathrm{p}_{\mathrm{a}} / \mathrm{p}_{\mathrm{x}}\right), \sigma\right] .
\end{aligned}
$$

Replacing $\kappa$ in equation (7b) with $\mu\left[\phi,\left(\mathrm{p}_{\mathrm{a}} / \mathrm{p}_{\mathrm{x}}\right), \sigma\right]$ in equation (15) yields the modified formula for $\lambda^{*}$ in equations (13).

\footnotetext{
${ }^{5}$ These newly defined factor shares sum to unity: $\mu[]+.(1-\mu[]$. $=\phi^{\sigma}\left(\mathrm{p}_{\mathrm{a}} / \mathrm{p}_{\mathrm{x}}\right)^{1-\sigma}+(1-\phi)^{\sigma}\left(\mathrm{p}_{\mathrm{b}} / \mathrm{p}_{\mathrm{x}}\right)^{1-\sigma}=\left(\phi^{\sigma} \mathrm{p}_{\mathrm{a}}{ }^{1-\sigma}+(1-\phi)^{\sigma} \mathrm{p}_{\mathrm{b}}{ }^{1-\sigma}\right) \mathrm{p}_{\mathrm{x}}{ }^{-(1-\sigma)}$. The expression in parentheses can be related to $\mathrm{p}_{\mathrm{x}}$ with equation (10); hence, $\mathrm{p}_{\mathrm{x}}^{(1-\sigma)} \mathrm{p}_{\mathrm{x}}{ }^{-(1-\sigma)}=1$.
} 


\section{Re-evaluating Marshall's Four Rules}

Hicks used his formula to evaluate Marshall's Four Rules of derived demand. He cast the Four Rules in terms of the response of $\lambda$ (equation (6)) to four parameters $(\sigma, \kappa, e, \eta)$, and he confirmed that three of the four rules were valid. Hicks' formal analysis did highlight that Marshall's Second Rule was not generally true and depended on the sign of $(\eta-\sigma)$. Since the correction factor, $\mu\left[\phi,\left(\mathrm{p}_{\mathrm{a}} / \mathrm{p}_{\mathrm{x}}\right), \sigma\right]$, is always positive and only involves the parameter $\sigma$, Hicks' analysis of three of Marshall's Rules remain valid. However, the modified formula demonstrates that the first of Marshall's Four Rules is problematic. The First Rule (Hicks, 1932/1963, p. 242) is as follows,

I. "The demand for anything is likely to be more elastic, the more readily substitutes for that thing can be obtained."

Following Hicks, we evaluate this Rule in terms of the derivative of $\lambda^{*}$ with respect to $\sigma$,

$$
\partial \lambda^{*} / \partial \sigma=1-\mu[.]+(\eta-\sigma)\left(\operatorname{Ln}[\phi]-\operatorname{Ln}\left[p_{\mathrm{a}} / \mathrm{p}_{\mathrm{x}}\right]\right) \mu[.]
$$

When this derivative is based on Hicks' original formula, only the first two terms appear and, since $\mu[$.$] lies between 0$ and 1 , the derivative is always positive, thus confirming Marshall's First Rule. However, under the modified formula and as captured in the third term, the derivative is also affected by variation in the factor share. The sign of this additional term is indeterminate and depends on the relations among $\eta, \sigma, \phi$, and $\left(\mathrm{p}_{\mathrm{a}} / \mathrm{p}_{\mathrm{x}}\right)$. Even if quantities and prices are defined such that the relative price entering equation (16) is unity, the indeterminacy remains, and Marshall's First Rule is not generally valid. 


\section{Appendix}

This appendix derives the modified Hicks formula when the price elasticity of supply of the substitute factor $b$, e, is finite. We begin with the equation for the derived demand for factor a (equation (12),

$$
\mathrm{a}=\phi^{\sigma} \mathrm{p}_{\mathrm{a}}{ }^{-\sigma}\left(\phi^{\sigma} \mathrm{p}_{\mathrm{a}}^{(1-\sigma)}+(1-\phi)^{\sigma} \mathrm{p}_{\mathrm{b}}^{(1-\sigma)}\right)^{((\sigma-\eta) /(1-\sigma))} \mathrm{W}
$$

Taking logarithms of equation (A1), we obtain the following equation,

$$
\begin{aligned}
\ln \mathrm{a} & =\sigma \ln \phi-\sigma \ln \mathrm{p}_{\mathrm{a}}+\left(\frac{\sigma-\eta}{1-\sigma}\right) \ln \left[\phi^{\sigma} \mathrm{p}_{\mathrm{a}}^{1-\sigma}+(1-\phi)^{\sigma} \mathrm{p}_{\mathrm{b}}^{1-\sigma}\right] \\
& +\ln \mathrm{W} .
\end{aligned}
$$

Differentiating equation (A2) w.r.t. $\mathrm{p}_{\mathrm{a}}$ and recognizing the relations among $\mathrm{p}_{\mathrm{a}}, \mathrm{b}$, and $\mathrm{p}_{\mathrm{b}}$, we obtain the following derivative,

$$
\begin{aligned}
\frac{(\partial \mathrm{a} / \mathrm{a})}{\left(\partial \mathrm{p}_{\mathrm{a}} / \mathrm{p}_{\mathrm{a}}\right)} & =-\sigma+(\sigma-\eta)\left\{\phi^{\sigma}\left(\mathrm{p}_{\mathrm{a}} / \mathrm{p}_{\mathrm{x}}\right)^{1-\sigma}\right\} \\
& +(\sigma-\eta)\left\{(1-\phi)^{\sigma}\left(\mathrm{p}_{\mathrm{b}} / \mathrm{p}_{\mathrm{x}}\right)^{1-\sigma} \frac{\partial \mathrm{p}_{\mathrm{b}}}{\partial \mathrm{b}} \frac{\partial \mathrm{b}}{\partial \mathrm{p}_{\mathrm{a}}} \frac{\mathrm{p}_{\mathrm{a}}}{\mathrm{p}_{\mathrm{b}}}\right\}
\end{aligned}
$$

Defining the cross-price elasticity of factor $b$,

$$
\varepsilon_{\mathrm{c}} \equiv(\partial \mathrm{b} / \mathrm{b}) /\left(\partial \mathrm{p}_{\mathrm{a}} / \mathrm{p}_{\mathrm{a}}\right)
$$


and using the definitions in equations (2), (4), and (13b), we can rewrite equation (A3) as follows,

$$
\lambda^{*}=\sigma-(\sigma-\eta) \mu[\cdot]-(\sigma-\eta)(1-\mu[\cdot])\left(\varepsilon_{\mathrm{c}} / \mathrm{e}\right)
$$

The problematic element in equation (A5) is $\varepsilon_{\mathrm{c}}$. We eliminate this crossprice elasticity by analyzing the derived demand for factor $b$ w.r.t. variations in $p_{a}$. Paralleling the above analysis of the derived demand for factor a, we start with the equation for the derived demand for factor $b$ (similar to equation (12)),

$$
\mathrm{b}=(1-\phi)^{\sigma} \mathrm{p}_{\mathrm{b}}-\sigma\left(\phi^{\sigma} \mathrm{p}_{\mathrm{a}}^{(1-\sigma)}+(1-\phi)^{\sigma} \mathrm{p}_{\mathrm{b}}{ }^{(1-\sigma)}\right)^{((\sigma-\eta) /(1-\sigma))} \mathrm{W}, \text { (A6) }
$$

take logarithms of equation (A6), and obtain the following equation,

$$
\begin{aligned}
\ln b & =\sigma \ln (1-\phi)-\sigma \ln p_{b}+\left(\frac{\sigma-\eta}{1-\sigma}\right) \ln \left[\phi^{\sigma} p_{a}^{1-\sigma}+(1-\phi)^{\sigma} p_{b}^{1-\sigma}\right] \\
& +\ln \mathrm{W}
\end{aligned}
$$

Differentiating equation (A7) w.r.t. $\mathrm{p}_{\mathrm{a}}$ and recognizing the relations among $\mathrm{p}_{\mathrm{a}}, \mathrm{b}$, and $\mathrm{p}_{\mathrm{b}}$, we obtain the following derivative,

$$
\begin{aligned}
\frac{(\partial \mathrm{b} / \mathrm{b})}{\left(\partial \mathrm{p}_{\mathrm{a}} / \mathrm{p}_{\mathrm{a}}\right)} & =-\sigma \frac{\partial \mathrm{p}_{\mathrm{b}}}{\partial \mathrm{b}} \frac{\partial \mathrm{b}}{\partial \mathrm{p}_{\mathrm{a}}} \frac{\mathrm{p}_{\mathrm{a}}}{\mathrm{p}_{\mathrm{b}}}+(\sigma-\eta)\left\{\phi^{\sigma}\left(\mathrm{p}_{\mathrm{a}} / \mathrm{p}_{\mathrm{x}}\right)^{1-\sigma}\right\} \\
& +(\sigma-\eta)\left\{(1-\phi)^{\sigma}\left(\mathrm{p}_{\mathrm{b}} / \mathrm{p}_{\mathrm{x}}\right)^{1-\sigma} \frac{\partial \mathrm{p}_{\mathrm{b}}}{\partial \mathrm{b}} \frac{\partial \mathrm{b}}{\partial \mathrm{p}_{\mathrm{a}}} \frac{\mathrm{p}_{\mathrm{a}}}{\mathrm{p}_{\mathrm{b}}}\right\}
\end{aligned}
$$


Again using the definitions in equations (2), (4) and (13b), equation (A8) can be rewritten as follows,

$$
\varepsilon_{\mathrm{c}}=-\sigma\left(\varepsilon_{\mathrm{c}} / \mathrm{e}\right)+(\sigma-\eta) \mu[\cdot]+(\sigma-\eta)(1-\mu[\cdot])\left(\varepsilon_{\mathrm{c}} / \mathrm{e}\right)
$$

Equation (A9) can be solved for $\left(\varepsilon_{\mathrm{c}} / \mathrm{e}\right)$,

$$
\left(\varepsilon_{\mathrm{c}} / \mathrm{e}\right)=\frac{(\sigma-\eta) \mu[\cdot]}{\eta+\mathrm{e}+(\sigma-\eta) \mu[\cdot]}
$$

Returning to the price elasticity of demand for factor a, we use equation (A10) to eliminate the cross-price elasticity term in equation (A5) and, after substantial manipulation, obtain the following equation,

$$
\lambda=\frac{\sigma(\eta+\mathrm{e})+\mathrm{e}(\eta-\sigma) \mu[\cdot]}{\eta+\mathrm{e}-(\eta-\sigma) \mu[\cdot]} .
$$

Equation (A11) is equation (6) in the text with the sole modification that our $\mu[$.] replaces Hicks's $\kappa$. 


\section{References}

Allen, R.G.D., Mathematical Analysis for Economists (London: MacMillan \& Co., 1938; reprinted, New York: St. Martin's Press, 1964).

Arrow, Kenneth J., Chenery, Hollis B., Minhas, Bagicha S., and Solow, Robert M., "Capital-Labor Substitution and Economic Efficiency," Review Of Economics And Statistics 43 (1961), 225-250; reprinted in Production and Capital: Collected Papers of Kenneth J. Arrow Vol. 5 (Cambridge: Harvard University Press, 1985), 50-103.

Borjas, George J., Labor Economics, Third Edition (Boston: McGraw-Hill Irwin, 2005).

Chirinko, Robert S., and Mallick, Debdulal, "The Substitution Elasticity, Growth Theory, and The Low-Pass Filter Panel Model," Emory University (May 2006).

Ehrenberg, Ronald G., and Smith, Robert S., Modern Labor Economics, Ninth Edition (Boston: Pearson Addison Wesley, 2006).

Hamermesh, Daniel, Labor Demand (Princeton; Princeton University Press, 1993).

Hicks, John R., The Theory of Wages, Second Edition (London: MacMillan \& Co., 1963). First edition published in 1932.

Kaufman, Bruce E., and Hotchkiss, Julie L., The Economics of Labor Markets, Sixth Edition (Mason, Ohio: Thomson/South-Western, 2003).

Molina, Mario Garcia, "Capital Theory and the Origins of the Elasticity of Substitution," Cambridge Journal of Economics 29 (2005), 423-437.

Robinson, Joan, The Economics of Imperfect Competition (London: MacMillan \& Co., 1933; Reprinted 1959). 


\section{CESifo Working Paper Series}

(for full list see www.cesifo-group.de)

1681 Wladimir Raymond, Pierre Mohnen, Franz Palm and Sybrand Schim van der Loeff, Persistence of Innovation in Dutch Manufacturing: Is it Spurious?, March 2006

1682 Andrea Colciago, V. Anton Muscatelli, Tiziano Ropele and Patrizio Tirelli, The Role of Fiscal Policy in a Monetary Union: Are National Automatic Stabilizers Effective?, March 2006

1683 Mario Jametti and Thomas von Ungern-Sternberg, Risk Selection in Natural Disaster Insurance - the Case of France, March 2006

1684 Ken Sennewald and Klaus Waelde, “Itô’s Lemma“ and the Bellman Equation for Poisson Processes: An Applied View, March 2006

1685 Ernesto Reuben and Frans van Winden, Negative Reciprocity and the Interaction of Emotions and Fairness Norms, March 2006

1686 Françoise Forges, The Ex Ante Incentive Compatible Core in Exchange Economies with and without Indivisibilities, March 2006

1687 Assar Lindbeck, Mårten Palme and Mats Persson, Job Security and Work Absence: Evidence from a Natural Experiment, March 2006

1688 Sebastian Buhai and Coen Teulings, Tenure Profiles and Efficient Separation in a Stochastic Productivity Model, March 2006

1689 Gebhard Kirchgaessner and Silika Prohl, Sustainability of Swiss Fiscal Policy, March 2006

1690 A. Lans Bovenberg and Peter Birch Sørensen, Optimal Taxation and Social Insurance in a Lifetime Perspective, March 2006

1691 Moritz Schularick and Thomas M. Steger, Does Financial Integration Spur Economic Growth? New Evidence from the First Era of Financial Globalization, March 2006

1692 Burkhard Heer and Alfred Maussner, Business Cycle Dynamics of a New Keynesian Overlapping Generations Model with Progressive Income Taxation, March 2006

1693 Jarko Fidrmuc and Iikka Korhonen, Meta-Analysis of the Business Cycle Correlation between the Euro Area and the CEECs, March 2006

1694 Steffen Henzel and Timo Wollmershaeuser, The New Keynesian Phillips Curve and the Role of Expectations: Evidence from the Ifo World Economic Survey, March 2006

1695 Yin-Wong Cheung, An Empirical Model of Daily Highs and Lows, March 2006 
1696 Scott Alan Carson, African-American and White Living Standards in the $19^{\text {th }}$ Century American South: A Biological Comparison, March 2006

1697 Helge Berger, Optimal Central Bank Design: Benchmarks for the ECB, March 2006

1698 Vjollca Sadiraj, Jan Tuinstra and Frans van Winden, On the Size of the Winning Set in the Presence of Interest Groups, April 2006

1699 Martin Gassebner, Michael Lamla and Jan-Egbert Sturm, Economic, Demographic and Political Determinants of Pollution Reassessed: A Sensitivity Analysis, April 2006

1700 Louis N. Christofides and Amy Chen Peng, Major Provisions of Labour Contracts and their Theoretical Coherence, April 2006

1701 Christian Groth, Karl-Josef Koch and Thomas M. Steger, Rethinking the Concept of Long-Run Economic Growth, April 2006

1702 Dirk Schindler and Guttorm Schjelderup, Company Tax Reform in Europe and its Effect on Collusive Behavior, April 2006

1703 Françoise Forges and Enrico Minelli, Afriat's Theorem for General Budget Sets, April 2006

1704 M. Hashem Pesaran, Ron P. Smith, Takashi Yamagata and Liudmyla Hvozdyk, Pairwise Tests of Purchasing Power Parity Using Aggregate and Disaggregate Price Measures, April 2006

1705 Piero Gottardi and Felix Kubler, Social Security and Risk Sharing, April 2006

1706 Giacomo Corneo and Christina M. Fong, What's the Monetary Value of Distributive Justice?, April 2006

1707 Andreas Knabe, Ronnie Schoeb and Joachim Weimann, Marginal Employment Subsidization: A New Concept and a Reappraisal, April 2006

1708 Hans-Werner Sinn, The Pathological Export Boom and the Bazaar Effect - How to Solve the German Puzzle, April 2006

1709 Helge Berger and Stephan Danninger, The Employment Effects of Labor and Product Markets Deregulation and their Implications for Structural Reform, May 2006

1710 Michael Ehrmann and Marcel Fratzscher, Global Financial Transmission of Monetary Policy Shocks, May 2006

1711 Carsten Eckel and Hartmut Egger, Wage Bargaining and Multinational Firms in General Equilibrium, May 2006

1712 Mathias Hoffmann, Proprietary Income, Entrepreneurial Risk, and the Predictability of U.S. Stock Returns, May 2006 
1713 Marc-Andreas Muendler and Sascha O. Becker, Margins of Multinational Labor Substitution, May 2006

1714 Surajeet Chakravarty and W. Bentley MacLeod, Construction Contracts (or "How to Get the Right Building at the Right Price?”), May 2006

1715 David Encaoua and Yassine Lefouili, Choosing Intellectual Protection: Imitation, Patent Strength and Licensing, May 2006

1716 Chris van Klaveren, Bernard van Praag and Henriette Maassen van den Brink, Empirical Estimation Results of a Collective Household Time Allocation Model, May 2006

1717 Paul De Grauwe and Agnieszka Markiewicz, Learning to Forecast the Exchange Rate: Two Competing Approaches, May 2006

1718 Sijbren Cnossen, Tobacco Taxation in the European Union, May 2006

1719 Marcel Gérard and Fernando Ruiz, Interjurisdictional Competition for Higher Education and Firms, May 2006

1720 Ronald McKinnon and Gunther Schnabl, China's Exchange Rate and International Adjustment in Wages, Prices, and Interest Rates: Japan Déjà Vu?, May 2006

1721 Paolo M. Panteghini, The Capital Structure of Multinational Companies under Tax Competition, May 2006

1722 Johannes Becker, Clemens Fuest and Thomas Hemmelgarn, Corporate Tax Reform and Foreign Direct Investment in Germany - Evidence from Firm-Level Data, May 2006

1723 Christian Kleiber, Martin Sexauer and Klaus Waelde, Bequests, Taxation and the Distribution of Wealth in a General Equilibrium Model, May 2006

1724 Axel Dreher and Jan-Egbert Sturm, Do IMF and World Bank Influence Voting in the UN General Assembly?, May 2006

1725 Swapan K. Bhattacharya and Biswa N. Bhattacharyay, Prospects of Regional Cooperation in Trade, Investment and Finance in Asia: An Empirical Analysis on BIMSTEC Countries and Japan, May 2006

1726 Philippe Choné and Laurent Linnemer, Assessing Horizontal Mergers under Uncertain Efficiency Gains, May 2006

1727 Daniel Houser and Thomas Stratmann, Selling Favors in the Lab: Experiments on Campaign Finance Reform, May 2006

1728 E. Maarten Bosker, Steven Brakman, Harry Garretsen and Marc Schramm, A Century of Shocks: The Evolution of the German City Size Distribution 1925 - 1999, May 2006

1729 Clive Bell and Hans Gersbach, Growth and Enduring Epidemic Diseases, May 2006 
1730 W. Bentley MacLeod, Reputations, Relationships and the Enforcement of Incomplete Contracts, May 2006

1731 Jan K. Brueckner and Ricardo Flores-Fillol, Airline Schedule Competition: ProductQuality Choice in a Duopoly Model, May 2006

1732 Kerstin Bernoth and Guntram B. Wolff, Fool the Markets? Creative Accounting, Fiscal Transparency and Sovereign Risk Premia, May 2006

1733 Emmanuelle Auriol and Pierre M. Picard, Government Outsourcing: Public Contracting with Private Monopoly, May 2006

1734 Guglielmo Maria Caporale and Luis A. Gil-Alana, Modelling Structural Breaks in the US, UK and Japanese Unemployment Rates, May 2006

1735 Emily J. Blanchard, Reevaluating the Role of Trade Agreements: Does Investment Globalization Make the WTO Obsolete?, May 2006

1736 Per Engström and Bertil Holmlund, Tax Evasion and Self-Employment in a High-Tax Country: Evidence from Sweden, May 2006

1737 Erkki Koskela and Mikko Puhakka, Cycles and Indeterminacy in Overlapping Generations Economies with Stone-Geary Preferences, May 2006

1738 Saku Aura and Thomas Davidoff, Supply Constraints and Housing Prices, May 2006

1739 Balázs Égert and Ronald MacDonald, Monetary Transmission Mechanism in Transition Economies: Surveying the Surveyable, June 2006

1740 Ben J. Heijdra and Ward E. Romp, Ageing and Growth in the Small Open Economy, June 2006

1741 Robert Fenge and Volker Meier, Subsidies for Wages and Infrastructure: How to Restrain Undesired Immigration, June 2006

1742 Robert S. Chirinko and Debdulal Mallick, The Elasticity of Derived Demand, Factor Substitution and Product Demand: Corrections to Hicks' Formula and Marshall's Four Rules, June 2006 